Ann. Zootech., I980, 29 (3), 245-263.

\title{
The relative biological availability of phosphorus in feed phosphates for broilers $\left({ }^{*}\right)$
}

\author{
G. HUYGHEBAERT, G. DE GROOTE and L. KEPPENS \\ Ministry of Agriculture \\ Agricultural Research Administration \\ Government Agricultural Research Centre - Ghent \\ Government Research Station for Small Stock Husbandry \\ Burg. Van Gansberghelaan, 92, 9220 Merelbeke (Belgique)
}

\begin{abstract}
Summary
The relative biological values (R.B.V.) of the following feed phosphates were investigated: two monocalciumphosphates (MCP), two hydrated dicalcium phosphates (DCP), two anhydrous dicalciumphosphates (AnDCP), two defluorinated rock phosphates (DFP), one $\mathrm{Ca}-\mathrm{Mg}-\mathrm{Na}$ phosphate (CMP), one mono-Na-phosphate (MSP), one di-Na-phosphate (DSP) (= reference P-source), a meat-and-bone meal (MBM) and a Ca-Al-Fe-phosphate (CAP). Two successive experiments were carried out: an increasing Ca: P-ratio ( $\mathrm{I}^{\mathrm{e}}$ experiment) or a constant Ca-level (ze experiment). The effect of the Na: Cl-ratio upon the R.B.V. also received attention. The features of the tibia (breaking strength, ash-content, ash-percentage and P-content) were only considered to calculate the R.B.V.

The broilers were kept in cages, under normal environmental circumstances (deionized water). The P-deficient experimental rations were equally fed to all the uniform test groups during a period of intense mineral anabolism (7-20 days).

The results of both experiments were very similar to each other (I-8 p. IOo). Averaged for the two experiments, the following R.B.V. were found in comparison to $\operatorname{DSP}(=\mathrm{IOO})$ : $\mathrm{MCP}$ $\neq \mathrm{A}($ source $\mathrm{A})=98, \mathrm{MCP} \neq \mathrm{B}=93, \mathrm{DCP} \neq \mathrm{A}=\mathrm{IOI}, \mathrm{DCP} \neq \mathrm{B}=92, \mathrm{An} \mathrm{DCP} \neq \mathrm{A}=86$, An $\mathrm{DCP} \neq \mathrm{B}=86, \mathrm{DFP} \neq \mathrm{A}=96, \mathrm{DFP} \neq \mathrm{B}=95, \mathrm{CMP}=102, \mathrm{MSP}=96, \mathrm{MBM}=90$ and $\mathrm{CAP}=\mathrm{I} 5 \mathrm{p}$. roo. Clear differences in ammonium citrate-(2 p. Ioo) solubility do not correlate with analogous R.B.V.-differences. The P-utilization (retention) was markedly favoured by an increasing $\mathrm{Na}$ : Cl-ratio in the feed, combined with a metabolizable anion.
\end{abstract}

\section{Introduction}

The great progress made in recent years in the field of feed formulation is first of all due to a better knowledge of the chemical composition of the feed ingredients and more recently to a better qualitative evaluation of the raw materials, e.g. the feed phosphates. These P-sources have to be add to the rations, because

(*) Research carried out with the financial support of the Institute of the Encouragement of Scientific Research in Industry and Agriculture (I.W.O.N.I.). 
the (available) phosphorus-supply of plant materials is insufficient to meet the phosphorus-requirements of broilers.

The methodology to determine the (relative) biological utilization of feed phosphates is very complex. Originally the aim was to find fast and simple techniques, e.g. chemical in vitro-techniques (GILIIS, NorRIS and HEUSER, I948; Anderson, Creug and Burroughs, I966; Nelson and Mrles, I973). However, it became evident that there was a very slight correlation with in vivo-experiments. Consequently to obtain more realistic information, biological tests had to be relied upon. As a result of the diversity of the methods applied, only the most interesting tendencies are briefly described in the present study.

The availability of phosphorus can be determined by digestibility experiments as outlined by GUEGUEN (I965), by the Göttingen-transponierings-test from GuNTHER and TEKIN (I968) or by the "percentage bone ash" criterium (Fnglish literature). The latter method, generally used in poultry experiments, is based on a (linear) relationship between bone ash (tibia) and the percentage of supplemental phosphorus (expressed or not in logarithms), in so far the P-level remains inferior to the P-requirement. Nevertheless, differences in relative biological value (R.B.V.), mentioned in the literature, are due to several factors, which influence the P-utilization (mineral anabolism): basal diet (GILLIS, EDWARDs and Young, I962; PENSACK and STOCKSTADT, I 96I; FRITZ et al., I969), animal (GILLIS, EDWARDS and Young, I962), vitamine $\mathrm{D}_{3}$-level (FrITZ et al., I969), Ca /P-relationship (Waldroup, Ammerman and Harms, I965; DAMron and Harms, I970), Na/Cl-ratio (MONGIN, I968; BARzEL, I969; NEWELI and BEAUCHENE, I975), length of trial period (AMmerman et al., I961; DilworTH and DAy, I964; NELson and PEELER, I96I). The calculation of the R.B.V. is usually based on the three following techniques: the abcissa-method (GILLIS, NORRIS and HEUSER, I948), the ordinate-method (BARUAH et al., I960) and the slope ratio-method (HURWITz, I 964; YoshidA and Hoshir, I977). SullivaN (I966) however, combined the three criteria (percent bone ash, weight gain and feed conversion) in a multifactorial regression equation for the calculation of the relative biological utilization values.

This brief survey of literature on the subject shows that a great number of nutritional and physiological factors influence P-utilization by poultry. This, together with some attendant problems with respect to the methodology used explains why the authors disagree on the extent to which the various $P$-sources are biologically utilized.

Bearing this in mind, the objective was to determine the relative biological utilization of $\mathrm{P}$ in various feed phosphates by means of two trials in vivo with broiler chickens.

This investigation was limited to the main feed phosphates, from which the formulator and or the computor must practically make a choice on the basis of their composition ( $\mathrm{P}, \mathrm{Ca}, \mathrm{Na}, \mathrm{F})$, the biological availability of $\mathrm{P}$ and the price. This investigation comprised: mono-calcium and dicalcium phosphates (hydrous and anhydrous), monosodium- and disodium-phosphates, defluorinated phosphates (DFP), a Ca-Mg-Na phosphate and meat-and-bone meal, all of which are sources of phosphorus with a rather good P-utilization. In order to make interpretation of the results easier, a Ca-Al-Fe-phosphate, which has a poor P-availability for chicks, was included in the outline of the second experiment. The criteria investigated in these experiments were: weight gain, feed conversion, bone ash deposition, percent bone ash, P-retention in the bones and the breaking strength of the tibia. The most important experimental variable studied was the effect of the Ca: P-ratio and of the Na: Cl-ratio. 


\section{Materials and methods}

\section{A. - General considerations}

In order to be able to compare the effect of the various P-sources the following conditions must be fulfilled:

I. uniform test groups having a virtually identical mean and distribution of body weight at the beginning of the test period;

2. an equal feed intake per animal-day (pair feeding system), so, provided that there are no interactions with the Ca-level, the contribution of organic $\mathrm{P}$ is the same for all test groups (WATkINS and MITCHEIL, I936). Thus, growth improvement occuring at increasing P-levels can only be attributed to a better feed conversion (NEISON and MILES, I972 and I973);

3. the $\mathrm{P}$ (whole body): $\mathrm{P}$ (tibia)-ratio must be almost constant for all $\mathrm{P}$-sources and for all P-supplementations, so that it is sufficient to determine the composition of the tibia. Nevertheless, this ratio depends on age, on the composition of the ration and on environmental factors. In this way the determination of the tibia composition provides a measure for the whole P-retention and, to some extent, for the $\mathrm{P}$-absorption, in so far as the excretion of phosphorus through the urine may be considered to be constant.

\section{B. - Animals and housing}

The day-old chicks were housed in battery cages. During the first week the broilers were fed ad-libitum a starter ration with an optimal P-level. The trial period started at the age of one week and lasted for 3 weeks, in principle. During this period the chick is subject to a very intense mineral anabolism, resulting in extremely high feed requirements (GUNTHER and TEKIN, I968). When they were one week old the chicks (males: Ross - Ist trial, Hybro — 2nd trial) were individually weighed and grouped in classes of weight (interval of weight: Io gram). About 75 p. Ioo of the chicks belonging to the medium weight classes were grouped uniformly in test groups of $\mathrm{I}$ o chicks each. There were $\mathrm{I} 2$ animals per $\mathrm{m}^{2}$. During the experimental period, the feed intake was controlled in such a way that the average feed intake was the same for all experimental groups during the whole period. Because of many difficulties it was impossible to obtain an equal daily feed intake for all groups. When the chicks were 4 weeks old, they were weighed by group and killed. The surrounding meat and the cartilage was removed from the tibia's after they had been boiled for 5 minutes. Firstly, the breaking strength of the tibia's was determined: strength meter, Mark; distance between the points of support, $5 \mathrm{~cm}$ in the first trial and $3.5 \mathrm{~cm}$ in the second trial (shorter tibia's); unit of force: kilogram. Then the dry matter content was determined ( 6 hours, $65^{\circ} \mathrm{C}$ ) without any previous defatting of the tibia's. The ash-content was determined by means of an incineration at $580{ }^{\circ} \mathrm{C}$ for ro hours. The P-level of the ash was determined with a double way spectrophotometer $(430 \mathrm{~nm})$ (phospho-vanadomolybdate of ammonium). The extent to which the P-body: P-tibia ratio was independent of the P-level of the ration was verified only in the first trial. These determinations were carried out in the presence of one P-source. 


\section{C. - The composition of the rations}

Table I shows the composition of the sources of phosphorus used for the investigation and table 2 mentions both the composition of the basic rations and the Ca-and P-levels of the various supplements for both experiments. This indicates the composition of the basic ration had to be adjusted to the nature of the P-source. The rest $p$. Ioo of the diet comprises: a Ca-source $\left(\mathrm{CaCO}_{3}, \mathrm{CaCl}_{2} \cdot 2 \mathrm{H}_{2} \mathrm{O}\right)$, a Na-source $\left(\mathrm{NaCl} / \mathrm{NaHCO}_{3}, \mathrm{Na}_{2} \mathrm{SO}_{4}\right)$, a P-source and a supplementary material (to fulfill the roo p. Ioo, milo). When calculating the P-level or the metabolizable energy-content (M. E.-content) this supplementary milo was not taken into account. But, it is to be remarked that at the lowest P-supplementation the M.E.-content is about 2 p. Ioo higher than at the highest P-supplementation. In order to avoid possible effects on live weight gain and feed conversion the total quantity of soybean meal + balanced meat-and-bone meal ( + amino acids) was maintained at a constant level. For these test groups the variable supply of $P$ through soybean meal was taken into account.

In the Ist experiment there were $8 \mathrm{P}$-supplementations (I replicate); in the and experiment there were 4 supplements (2 replicates). Test groups without mineral P-supplementations (basal rations) were included only in the 2 nd experiment. Phosphorus was supplied only by the feed, since the broilers received

TABIE I

Composition of the tested P-sources

Composition des phosphates analysés

\begin{tabular}{|c|c|c|c|c|}
\hline P-sources & $\mathrm{Ca}(\%)$ & $\begin{array}{l}\text { P-total } \\
(\%)\end{array}$ & $\begin{array}{ccc}\% & \mathrm{P} & \text { soluble } \\
\text { in } & (*) & \text { citrate } \\
(2 \%) & \%\end{array}$ & $\mathrm{Na}(\%)$ \\
\hline I. Monocalcium phosphate : $\mathrm{MCP} \neq \mathrm{A}$ & 16.9 & 23.06 & 09 & 0.28 \\
\hline $\begin{array}{l}\text { 2. Monocalcium phosphate : MCP } \neq \mathrm{B} \\
\text { 3. Hydrated dicalcium phosphate : DCP }\end{array}$ & I6.83 & 23.15 & $\begin{array}{l}99 \\
99\end{array}$ & 0.072 \\
\hline 4. Hydrated dicalcium phosphate : & 25.65 & I 7.93 & 98 & 0.OII \\
\hline 5. Anhydrous dicalcium phosphate : An & $27 \cdot 32$ & 20.48 & 92 & 0.039 \\
\hline 6. Anhydrous dicalcium phosphate : An & 29.17 & $2 \mathrm{I} \cdot 3^{8}$ & 98 & 0.028 \\
\hline 7. Defluorinated rock phosphate : & $29 \cdot 73$ & 21.16 & 97 & 0.029 \\
\hline 8. Defluoritiated rock phosphate : & $3 \mathrm{I} .8 \mathrm{I}$ & 18.50 & 47.6 & 5.62 \\
\hline 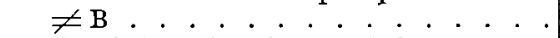 & $3 \mathrm{I} .8 \mathrm{I}$ & I 8.1 I & 67.1 & 4.94 \\
\hline 9. Ca-Mg-Na-phosphate : CMP. . . . . & 9.93 & 17.34 & 84 & I 1.55 \\
\hline Io. Di-sodiumphosphate : DSP . . & sp & 21.26 & IOO & 28.74 \\
\hline II. Meat-and-bone meal: MBM . . . . & I 2.09 & 5.80 & - & - \\
\hline I2. Mono-sodiumphosphate: MSP . . . . & $\mathrm{sp}$ & 19.8 & Ioo & $14 \cdot 7$ \\
\hline $\begin{array}{l}\text { I3. Ca-Al-Fe phosphate (Al: I9.3\%, Fe: } \\
6.4 \%, \mathrm{~F}: 0.95 \%): \mathrm{CAP} \cdot \ldots \cdot \cdots\end{array}$ & $7 \cdot 5$ & 14.5 & - & 0.6 \\
\hline
\end{tabular}

(*) P. 1 oo $\mathbf{P}$ soluble in citrate ( 2 p. I0o) : agitation in a solution of 2 p. xoo Ammoniumcitrate during $60 \mathrm{~min}$ at $20^{\circ} \mathrm{C}$. 
TABLE 2

Composition of the basal rations and the experimental diets

Composition des rations de base et des rations expérimentales

A. Composition of raze materials

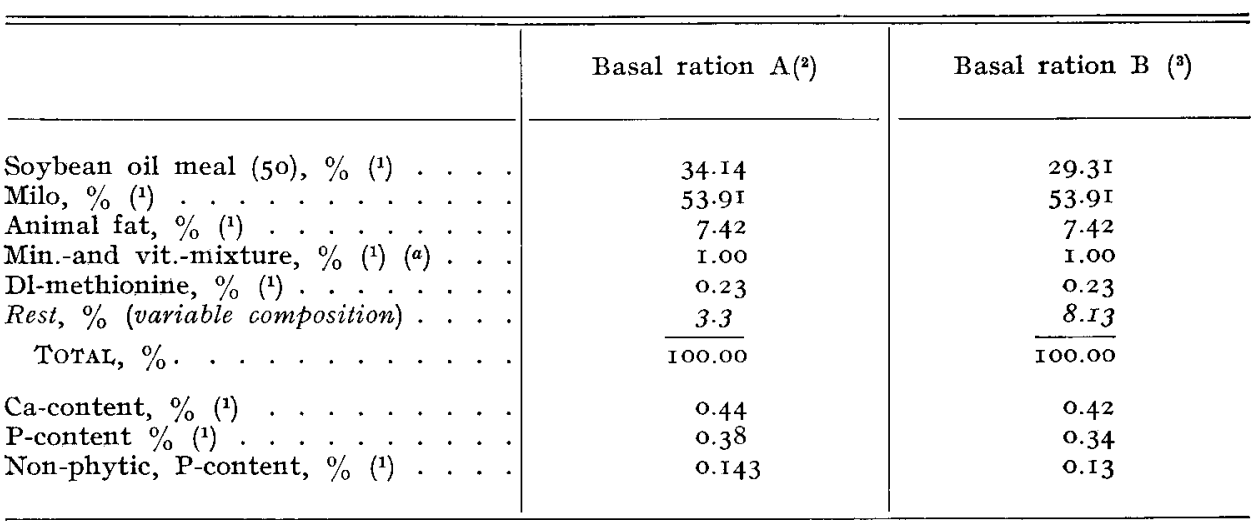

(I) Basal part, constant at each P-level.

(2) Basal part for the Ist expriment (P-sources : I-IO +12 ) and for the 2 nd experiment.

(3) Basal part for the Ist experiment (P-sources : II).

B. The Ca- and P-levels at the different P-supplementations (Istexperiment)

\begin{tabular}{|c|c|c|c|c|c|c|c|c|}
\hline & A & B & C & $\mathrm{D}$ & $\mathrm{E}$ & $\mathrm{F}$ & G & $\mathrm{H}$ \\
\hline Total Ca \% & 0.602 & 0.675 & 0.752 & 0.832 & 0.916 & 1.00 & 1.09 & I.19 \\
\hline Total $\mathbf{P} \%$. . . & 0.415 & 0.450 & 0.485 & 0.520 & 0.555 & 0.59 & 0.625 & 0.660 \\
\hline $\begin{array}{l}\text { Ca/P-ratio }{ }^{\text {Non-phytic }} \mathbf{P} \%(j) \\
\text { P-soturce }\end{array}$ & 1.45 & 1.50 & I. 55 & 1.60 & I. 65 & $1.7^{\circ}$ & 1.75 & 1.80 \\
\hline$(\mathrm{I}-\mathrm{IO}+\mathrm{I} 2)$ & 0.178 & 0.2 I 3 & 0.248 & 0.283 & 0.318 & 0.353 & 0.388 & 0.423 \\
\hline P-source $\mathrm{x}$. . . . & 0.219 & 0.253 & 0.286 & 0.319 & $0.35^{2}$ & $0.3^{8} 5$ & 0.418 & 0.453 \\
\hline
\end{tabular}

C. The Ca- and P-levels at the different P-supplementations (2nd experiment)

\begin{tabular}{|c|c|c|c|c|c|}
\hline & Basis (BA) & $A^{\prime}$ & $\mathrm{B}^{\prime}$ & $C^{\prime}$ & $\mathrm{D}^{\prime}$ \\
\hline $\begin{array}{llll}\text { Total Ca \% } & \cdot & \cdot & \cdot \\
\text { Total P } \% & \cdot & \cdot & \cdot \\
\text { Ca/P-ratio. } & \cdot & \cdot & \cdot \\
\text { Non-phytic P } & \% & (b)\end{array}$ & $\begin{array}{l}1.00 \\
0.380 \\
2.63 \\
0.143\end{array}$ & $\begin{array}{l}\text { I. } .00 \\
0.435 \\
2.30 \\
0.198\end{array}$ & $\begin{array}{l}1.00 \\
0.490 \\
2.04 \\
0.253\end{array}$ & $\begin{array}{l}\text { I. } .00 \\
0.545 \\
\text { I. } 83 \\
0.308\end{array}$ & $\begin{array}{l}1.00 \\
0.600 \\
1.67 \\
0.363\end{array}$ \\
\hline
\end{tabular}

(a) The vitamine $\mathrm{D}_{3}$-level was about 2 7oo I.U. per $\mathrm{kg}$ complete diet.

(b) However the non-phytic P-content of the rations can be divided in two parts : firstly the biologically available plant phosphorus (Nelson, 1967) and secondly the added "inorganic " phosphorus. 
deionized water (ion exchanger). The Ca: P-ratio did not remain constant when the P-level increased. The Ca: P-ratio increased with increasing P-levels (Ist experiment). This method yields higher percentages of bone ash (WALDROUP, AMMERMAN and HARMS, I965) than the use of a constant Ca-level or a constant Ca: P-ratio. In the 2 nd experiment the $\mathrm{Ca}-1$ evel was maintained constant, whereas the P-level increased. This method results in a greater increase of the percent bone ash, mainly since the Ca: P-ratio is too great at the lower P-levels. The Na: Cl-ratio has a considerable effect on the acid-base balance of the body and, hence, also on the live weight gain and the process of mineralization. The optimal Na: Cl-ratio nearly equals I and is independent of the Na-level and the Cl-level of the ration (Hurwitz et al., I973). In the first experiment, the $\mathrm{Na}$ - or the Cl-level was 0.I75 p. Ioo for most of the test groups, except for the groups with $\mathrm{P}$-sources that were rich in sodium. In the second experiment the minimum $\mathrm{Na}$ - or Cl-level was o.I5 p. Ioo (table 3). Also, in the second experiment $3 \mathrm{Na}$ - Cl ratio's were applied to one source of phosphorus (DCP $\neq \mathrm{A}$ ) : $\mathrm{Na}: \mathrm{Cl}=3: \mathrm{I}$ (with either $\mathrm{HCO}_{3}$ or $\mathrm{SO}_{4}^{-2}$ as a anion), $\mathrm{Na}: \mathrm{Cl}=\mathrm{I}$ and $\mathrm{Na}: \mathrm{Cl}=\mathrm{I}: 3$. However when calculating the linear regression equations, the basal ration taken into account was a ration with a $\mathrm{Na}$ : Cl-ratio equal to $I$.

TABIE 3

Survey of the experimental designs ( $r$ st and 2 nd experiment) : the $P$-sources with different $N$ a /Cl-ratios Revue du schéma expérimental ( $I^{\mathrm{re}}$ et $2^{\circ}$ expérimentation) : sources de phosphore et diftérents rapports de $\mathrm{Na} / \mathrm{Cl}$

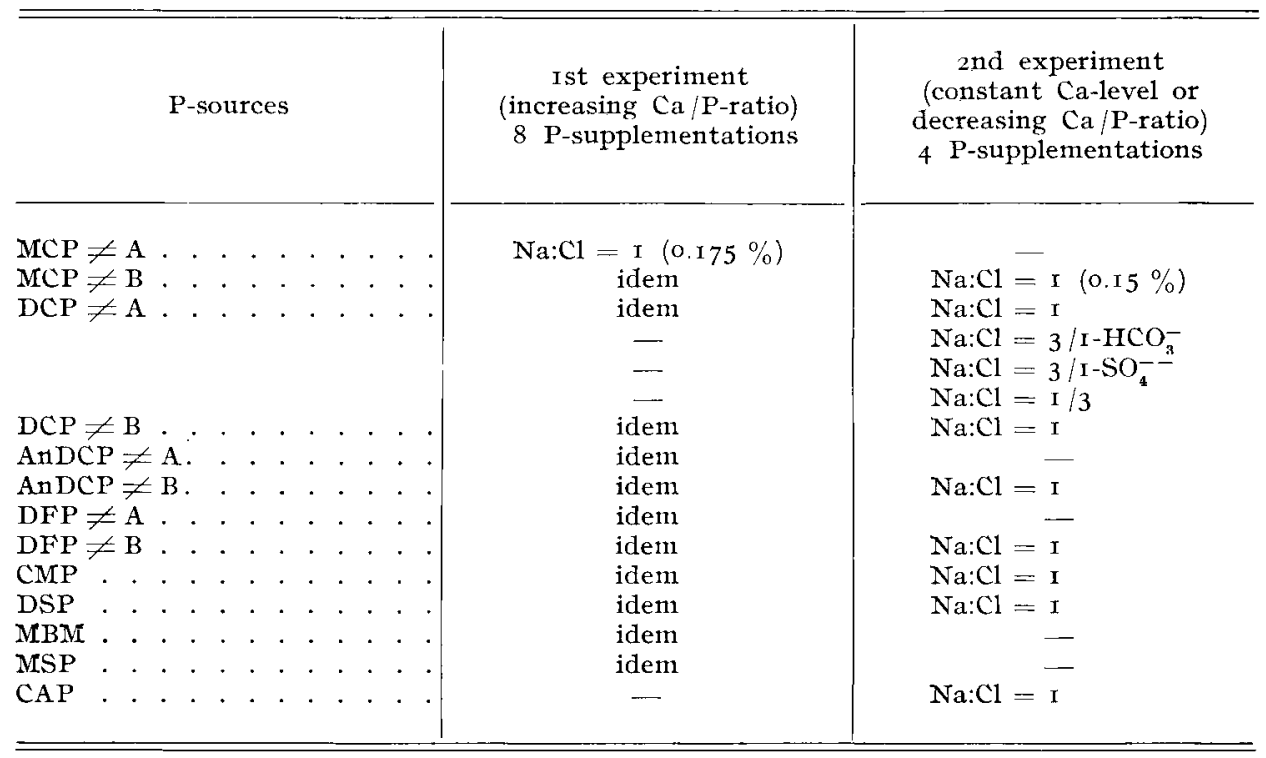

\section{D. - Calculations}

For the calculation of the linear regression equations the level of the nonphytic phosphorus (Ist experiment) or the level of added " inorganic " phosphorus (and experiment) was chosen as the independent variable for the four tibia para- 
meters. In the first experiment it was necessary to do so as the two basal rations used had a totally different P-level. As in the second experiment the birds were fed a basal ration that contained no supplemental inorganic $P$, we were able to use the corresponding data as a fixed point on the $x-y$ diagram that was common to all of the calculated linear regression equations. For reasons further explained in the section headed "Results and Discussion", the area under the linear regression lines was considered as a criterion of the biological utilization of phosphorus in the Ist experiment, whereas in the second experiment the slopes of the regression lines were used as a criterion of the R.B.V.

\section{Results and discussion}

The results of the investigated parameters, obtained at each $\mathrm{P}$-levels, are not mentioned to avoid no surveyable tables. On the other hand, these results are taken into account for the calculations of the linear regression equation in so far there was a linear relationship between the P-level and the above mentioned parameters (Tables 4 and 5). Table 6 summarizes the results regarding the R.B.V.

$$
\text { A. - Effect of the P-level (Ca-level) }
$$

\section{First experiment}

The application of a controlled feeding technique enabled the maintenance of an average feed intake, for the whole experimental period, at the same level for all experimental groups: about I $335 \mathrm{~g} /$ animal. The importance of this factor was indicated in the section "Trial Methods". The phosphorus consumed by the chicks is both organic and inorganic. At an equal food intake the share of the qualitatively unknown organic $\mathrm{P}$ may be considered to be constant. Thus. any effect on the feed efficiency on the body weight and on the tibia-parameters can only be due to a variable quantity of supplemented (available) inorganic P. An increase of the inorganic P-level (and of the Ca-level in the first experiment) had a favourable effect on both the live weight gain and the feed conversion. Moreover, all the calculated features of the tibia (breaking strength, ash-content, ashpercentage and P-level) continuously improved. Under the prevailing experimental conditions the $\mathrm{P}$ (body): $\mathrm{P}$ (tibia) - ratio amounted to $\mathrm{I} 7.95 \pm 0.46$ on average, with the P-level of the ration being $<0.6 \mathrm{p}$. Ioo. HuRwitz (I964) obtained a ratio of $19.6 \pm \mathrm{I}$. At higher P-levels the ratic amounted to $\mathrm{I} 6.8 \pm 0.8 \mathrm{I}$. This points to a relative gain of $P$ in the skeleton, c.q. in the tibia. Consequently, we may assume the P-level of the tibia as a good indicator of the amount of total phosphorus retained, when the $\mathrm{p} . \mathrm{I} 00$ of $\mathrm{P}$ in the ration is $<0.60 \mathrm{p}$. I00. There is a linear relationship between the above mentioned parameters and the P-level of the ration, as long as a particular P-level is not exceeded. For body weight gain, feed conversion, ash-content and P-level parameters, this particular P-level is $0.60 \mathrm{p}$. Ioo and for the tibia-ash percentage parameter it amounts to $0.66 \mathrm{p}$. Ioo. So, it is possible, with respect to this last parameter to carry out measurements in a greater linear area. When calculating the linear regression equations the values 


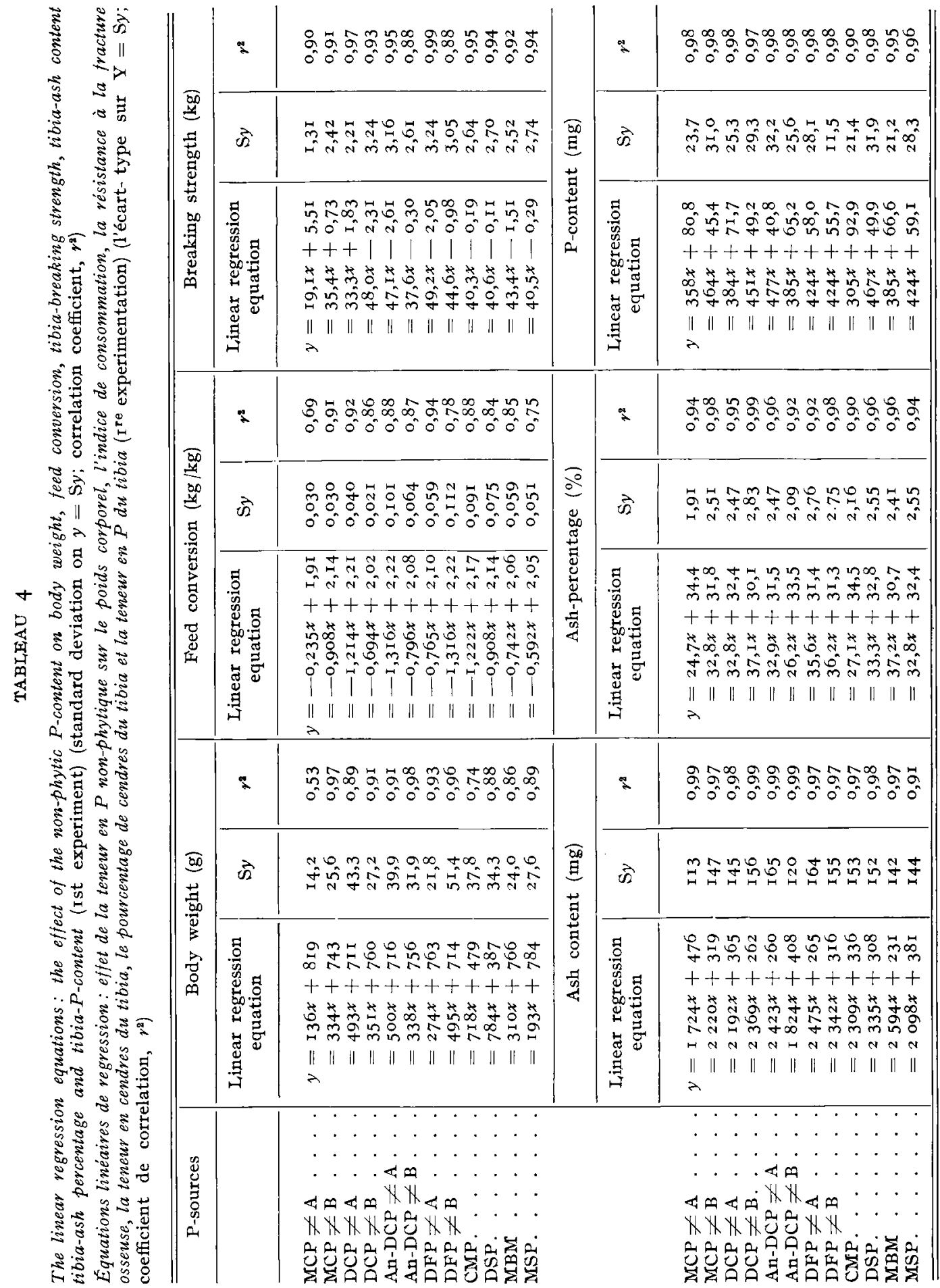




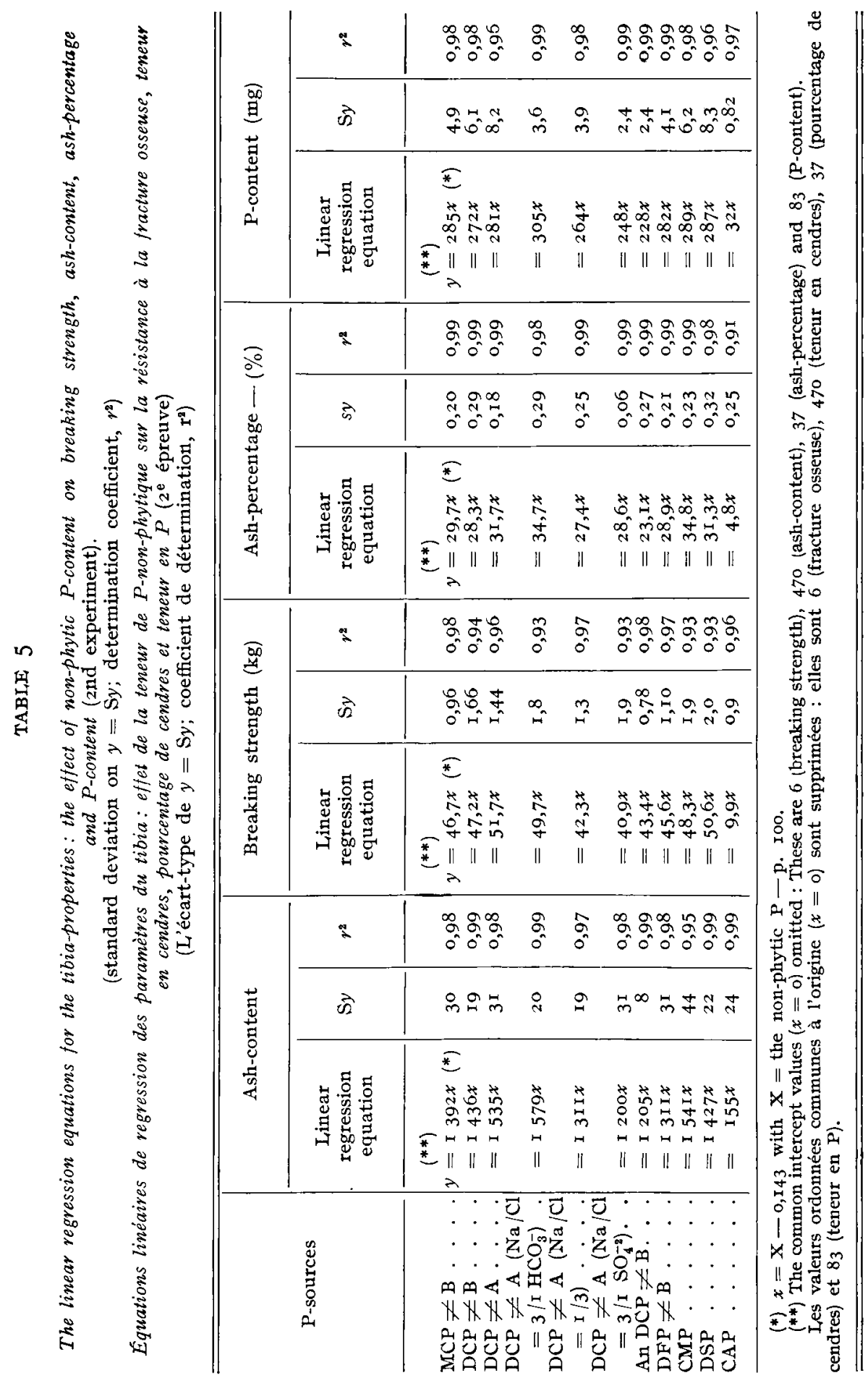


G. HUYGHEBAERT, G. DE GROOTE, L. KEPPENS

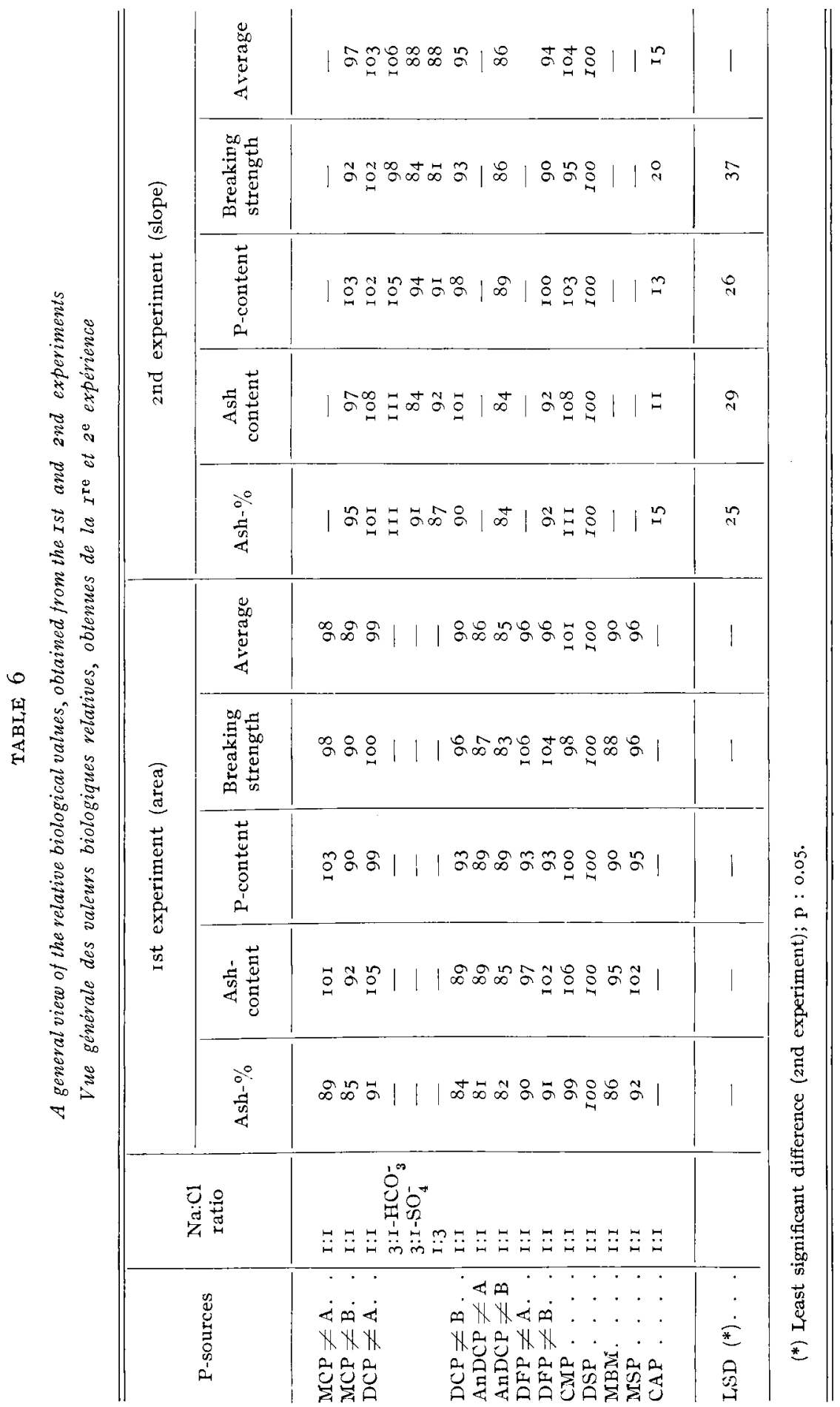


corresponding to P-levels above the already mentioned limits, were not taken into account. The linear relationship between the P-level of the ration or the P-intake by the chicks, on the one hand, and the parameters labeled ash-content, ash-percentage and P-level of the tibia on the other hand, may be qualified as "very good" for all the sources of phosphorus examined, as it is shown by the determination coefficients $\left(r^{2}\right)$ and the standard deviation (Sy) mentioned in table 4 and by figures I, 2 and 3 . This also holds, be it to a lesser extent, for the breaking strength. There are also high correlation coefficients between the various tibia-parameters above: $0.89-0.98(n=96)$. The lowest correlation coefficients relate to the "breaking strength" parameter. On the other hand, the relationship with the parameters " live weight gain" and "feed conversion" is clearly a non-linear and less accurate one, so that these parameters are not taken into account when determining the R.B.V.

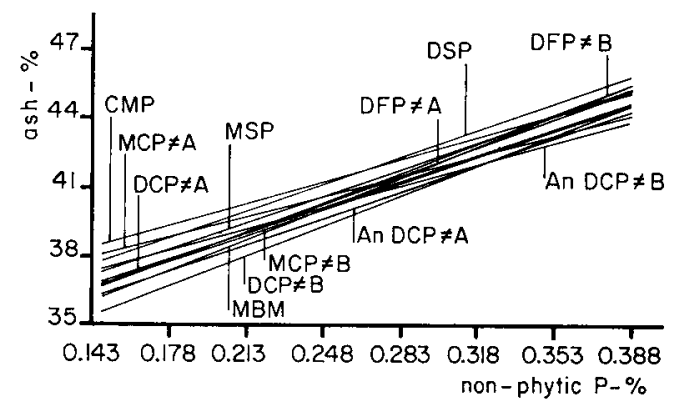

FIG. I. - The effect on non-phytic P-content on tibia ash percentage (Ist experiment). Effet de la teneur en $P$ non-phytique sur le pourcentage des cendres du tibia (Ire épreuve).

\section{Second experiment}

The feed intake was considerably lower than in the first experiment and amount on average to $854 \mathrm{~g}$ /animal for all test groups. In this experiment, both the body weight and the feed conversion were virtually independent of the P-level of the ration (fig. 2-3). Similar results were also obtained by HuRwiTz (I964). In this experiment the average final weight was $577 \mathrm{~g}$ and the average feed conversion was $\pm \mathrm{I} .73$.

Although there is no obvious explanation for this phenomenon, particular attention should be paid to the factors that, compared to the Ist experiment, were different, namely a constant Ca-level or a declining $\mathrm{Ca}$ : P-ratio and a low live weight gain, resulting from the lower feed intake (pair feeding system).

Consequently, an increase of the P-level only resulted in a considerable improvement of the features of the tibia. The linear relationship between the features of the tibia and the P-level covers a smaller P-supplementation area than in the previous experiment. Consequently, the upper limits of the various tibiaparameters are slightly lower than in the first experiment: $0.54 \mathrm{p}$. Ioo $\mathrm{P}$ for the breaking strength, the ash-content and the P-level and $0.57 \mathrm{p}$. Ioo for the ashpercentage respectively. On the basis of the non-phytic P-level of the ration (fig. 2) especially the ash-content and the P-level of the tibia are considerably lower than in the first experiment, whereas the breaking strength and the ash- 

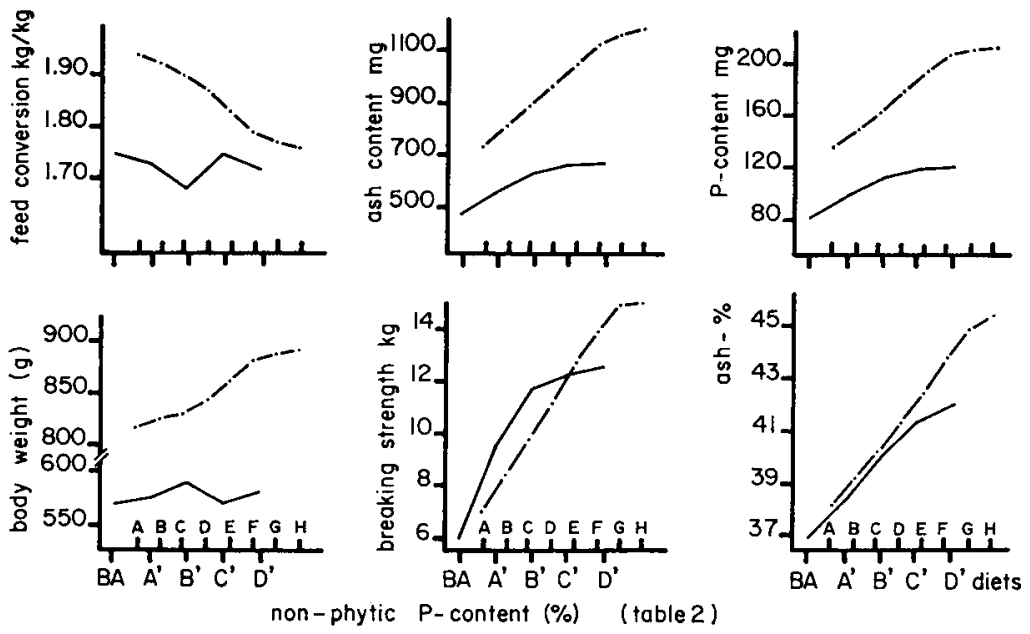

Fig. 2. - A comparison of the results, obtained from the Ist and 2nd experiment (average from all P-sources).

Comparaison des résultats, obtenus de la $I^{\mathrm{re}}$ et de la $2^{\mathrm{e}}$ épreuve

.-..... Ist experiment

and experiment
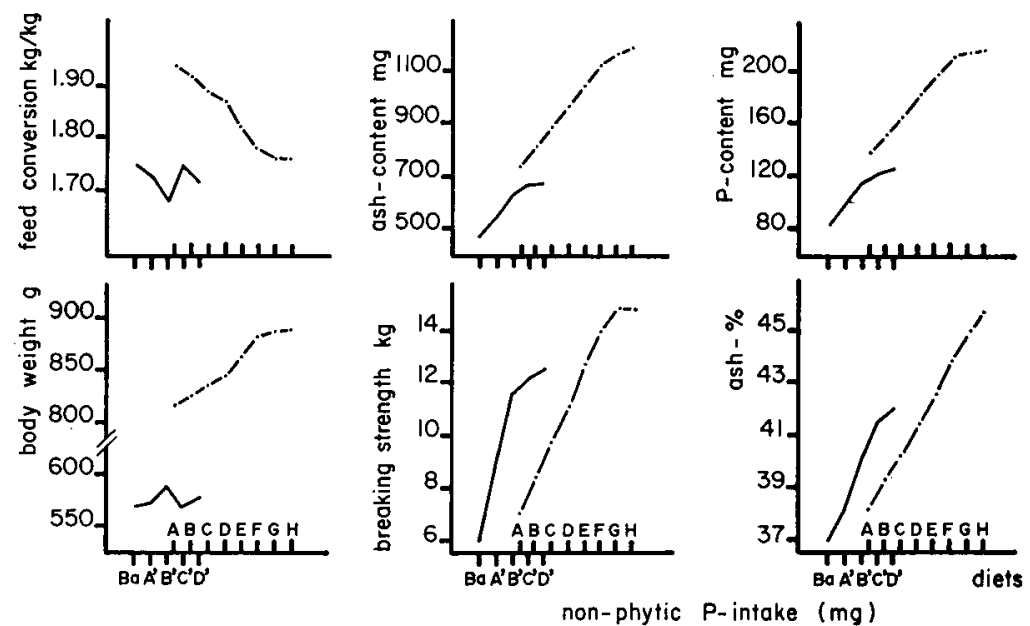

FIG. 3. - A comparison of the results, obtained from the Ist and and experiment (average for all P-sources).

Comparaison des résultats, obtenus de la $I^{\mathrm{re}}$ et $2^{\mathrm{e}}$ épreuve

(moyenne de toutes les sources de P).

Ist experiment

and experiment

percentage of the tibia differ only slightly from the analogous observations made in the first experiment. W'ith respect to the breaking strength attention should however be paid to the difference of the distance between the points of support used when determining the breaking strength, so that it is difficult to compare 
these observations. As for the ash-percentages it needs to be mentioned that this is in fact a ratio of two absolute values, i.e. the ash content (mg) and the total amount of dry matter of the tibia. Absolute values seemed to be more considerably influenced by breed, age, and feed intake than relative values (percentages). If the observations are expressed in terms of intake of non-phytic phosphorus (fig. 3), the response of ash deposition (ash content, mg) and P-retention (P-level, $\mathrm{mg}$ ) to increasing $\mathrm{P}$-supplements appears to be nearly parallel in both experiments. The ash-percentage, on the contrary, is clearly higher in the second trial, which is probably explained by the lower tibia-bone weights.

\section{B. - Effect of the nature of the sources of phosphorus}

More markedly than in the first experiment, linear response is missing between, on the one hand, the parameters "body weight - feed conversion" and the P-level of the ration on the other hand. The linear relationship between the

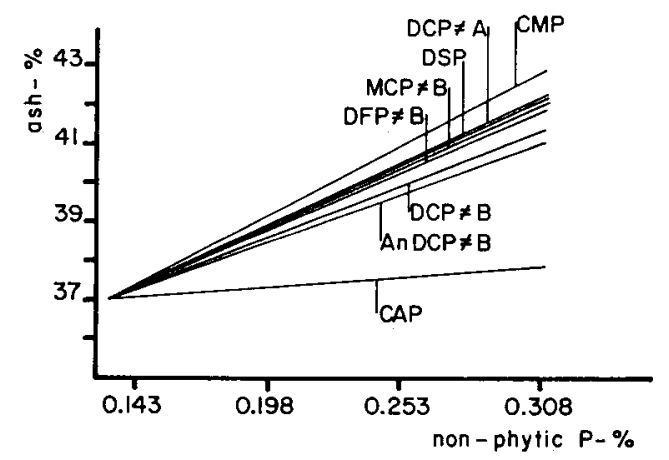

FrG. 4. - The effect of non-phytic P-content on tibia ash-percentage (2nd experiment).

Effet de la teneur en $P$ non-phytique sur le pourcentage des cendres du tibia ( 2 épreuve).

tibia-parameters and the P-level of the ration was, however, very good for all $P$-sources involved in the examination (Tables 4 and 5 , fig. $I$ and 4 ). It is for this reason as for the first experiment, that the parameters " body weight - feed conversion" were not taken into account when calculating the relative biological values (R.B.V.). Consequently, the R.B.V. are in both experiments based on the tibia-parameters. As, in a previously established $\mathrm{P}$-supplement area $(\leqslant$ optimal $P)$, there is a linear relationship between the tibia-parameters and the P-level of the ration, it is sufficient to compare the linear regression equations to each other. Different techniques have been used to this end:

1. The ordinate-method (BARUAH et al., I 960): at a previously fixed abscissa value the $y$-values are compared to each other. The P-source the regression of which yields the greatest $y$-value at one particular $x$-value is considered to be the best biological source.

2. The slope-method (Hurwitz, I964): the slopes of the linear equations were compared to each other. The P-source the regression of which has the greatest slope, presents the best P-utilization. 
3. The abscissa-method (GILIIS, NORRIS and HEUSER, I948): comparison of the abscissa's corresponding to a previously chosen ordinate. The P-source the regression equation of which has the lowest $x$-value, at one single $y$-value is the best biological source.

These methods may, or may not, lead to contradictory conclusions, when evaluating the R.B.V. In fact these contradictions are due to the situation of the linear regression lines (convergent-parallel-divergent) and to the (absolute) values necessary for the calculation of the relative biological values. If the lines are

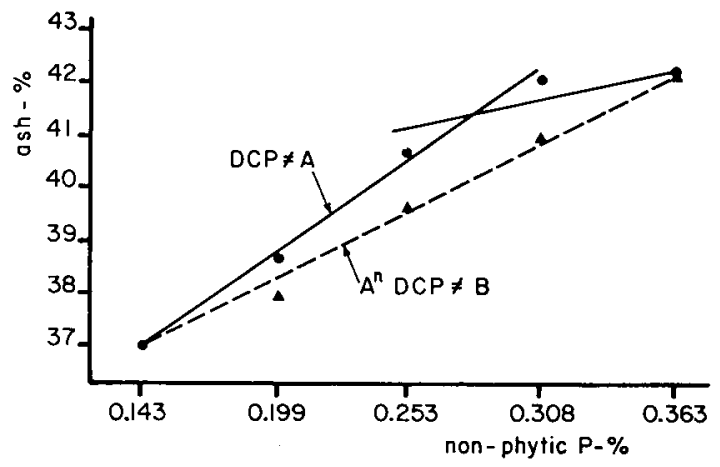

FIG. 5. - The effect of non-phytic P-content on tibia ash-percentage (and experiment: divergent-convergent).

Effet de la teneur en $P$ non-phytique sur le pourcentage des cendres du tibia $\left(2^{\mathrm{c}}\right.$ épreuve : divergent-convergent).

divergent (2nd experiment) the R.B.V.'s are independent of the interpretation technique and of the P-level of the ration. When the lines are convergent or parallel (Ist experiment) the R.B.V.'s are dependent of both the interpretation technique and the P-level of the ration. The order of the R.B.V.-classification obtained with the slope-method (convergent lines) is the opposite of the one obtained with the abscissa method, which leads to an exact evaluation. The choice of ordinates and abscissa's influences the R.B.V. in the case of convergent and parallel lines. So, it is necessary to calculate the average biological availability for the whole linear area. But, in order to avoid this complicated calculation, the area under the regression lines may be considered to be a representative estimate of the R.B.V. for the whole area of linear response to P-supplementation. It is striking that the experimental circumstances, e.g. the feed intake and the composition of the rations (the Ca: P-ratio), clearly influence the total picture of the regression lines convergent-parallel (Ist experiment) and divergent (2nd experiment). In the first experiment the Ca: P-balance was however more optimal than in the second experiment. If we consider the whole area of P-supplementation, high-grade sources of phosphorus show a rather asymptotic or logarithmic picture (fig. 5-2nd experiment), whereas the graphic of the less available sources is virtually linear. At increasing P-levels of the rations the originally divergent lines, change into parallel lines and finally show a convergent picture. So, the utilization of absorbed phosphorus derived from high grade sources of phosphorus is better when the P-supplementation is low. If the P-levels of the ration increase and the absorption coefficient remains constant, the mineral retention 
(ash and $\mathrm{P}$ in the tibia) will more markedly decline in the case of these sources than in the case of sources having a lower biological value. Consequently, it may be inferred that in the case of high-grade sources the physiological ashand P-saturation of the skeleton (tibia) will occur sooner, when the dietary Plevels increase, so that the $\mathrm{P}$-excretion in the urine will have a considerable effect upon the P-utilization. Table 6, which summarizes the R.B.V. of the P-sources examined here, proves that the various $P$-sources do not show very important differences in R.B.V. (maximum I5-20 p. I00), except for the Ca-Al-Fe-phosphate, the R.B.V. of which is very low and amounts to only I5 p. Ioo of the R.B.V. of disodium phosphate.

The results of the Ist and of the 2 nd experiment are very much alike (differences of I-8 p. I00), which means that the experimental circumstances, the Ca: P-ratio e.g., did virtually not influence the R.B.V. On the other hand, differences in R.B.V. occurred, according to which tibia-parameters had been chosen.

In this experiment there was not a close relationship between the $\mathrm{NH}_{4}^{+}-$ citrate solubility and the R.B.V.: the examined DFP with a low solubility have a rather high R.B.V., whereas the anhydrous DCP have a lower R.B.V., in spite of their greater solubility. This means that there are, in addition to the $\mathrm{NH}_{4}^{+}-$ citrate solubility, other factors, e.g. crystalline and chemical structure and impurities that have an effect upon the absorption and the utilization of the dietary phosphorus. On the other hand, the solubility in diluted citric acid solution - 0.5 p. IO0, Yoshida et al. (I979) and 2 p. IO0, GUEGUEN (I970) - can successfully be used as an index of biological availability.

Relative important differences in R.B.V. may occur between some analogous sources of phosphorus, e.g. \pm 9 p. Ioo between the two MCP and the two DCP, while there are virtually no differences for other analogous sources of phosphorus, in this case the anhydrous DCP and DFP.

This fact may be related to the manufacturing technique and to the attendant features of crystals; the important cause of the R.B.V. decrease is the presence of metaphosphate- and pyrophosphate- radicals, the level of which increases at higher manufacturing temperatures (MC GILLIVRAY, 1978). According to DAMRON and HARMS (I970) important R.B.V.-differences may occur between analogous sources of phosphorus (DFP, rock phosphates), whereas the R.B.V. of DCP appears to be some I2 p. Ioo lower than the R.B.V. of monosodium phosphate. The lower R.B.V. of anhydrous DCP, as compared to the R.B.V. of DCP-hydrated, appears clearly from our results, and are in agreement with those obtained by GILLIS, EDWARDS and Young (I962). Moreover, these authors claim the R.B.V. of MCP is markedly ( $\pm I_{5}$ p. IOo) better then the R.B.V. of DCP, which was not so apparent in our experiments. In general, conclusions drawn from the herein reported experiments, concerning the relative biological availability of $\mathrm{P}$ in different feed grade phosphates, are in agreement with the U.S.A. literature, in showing: (on poultry)

(I) that there can exist differences in R.B.V. of some IO-I5 P. Ioo between different sources of commercial DCP, of commercial MCP and of mixtures thereof (NELSON and WALKER, I964; PENSACK, I974, MC GiliriVRAY, I978).

(2) that anhydrous DCP is at least $I 5$ p. Ioo lower in R.B.V. than the dihydrate form of DCP (GII I IS, EDWARDS and Young, I962).

The generally observed higher biological availability of $5^{-I} 5 \mathrm{p}$. Ioo in monocalcium phosphates and in mono-disodium phosphates compared to dicalciumphosphate (Gil,is, Edwards and Young, I962; Neison and Wal,ker, I964; 
Pensack, 1974; Day, Mc Naughton and Dilworth, r973; Damron and Harms, I970; MC GILlivray, I978) is not confirmed by our experimental results. It demonstrates, in agreement with the work of FRITZ et al. (I969), that such difference is not always valid for all sources of these feed grade phosphates.

The studies of BRUNE und GÜNTHER (I96I) with rats and GÜNTHER (I966a, b) and GunTHER und TEKIN (I968) with rats and chicks have shown that the absence of vitamin $\mathrm{D}_{3}$ increases considerably the difference in biological efficiency between mono-and di-calcium phosphate, while in the presence of adequate amounts of vitamin $\mathrm{D}_{3}$ the difference becomes minor or disappears.

The R.B.V. found for the Ca-Mg-Na-phosphate shows that the phosphorus

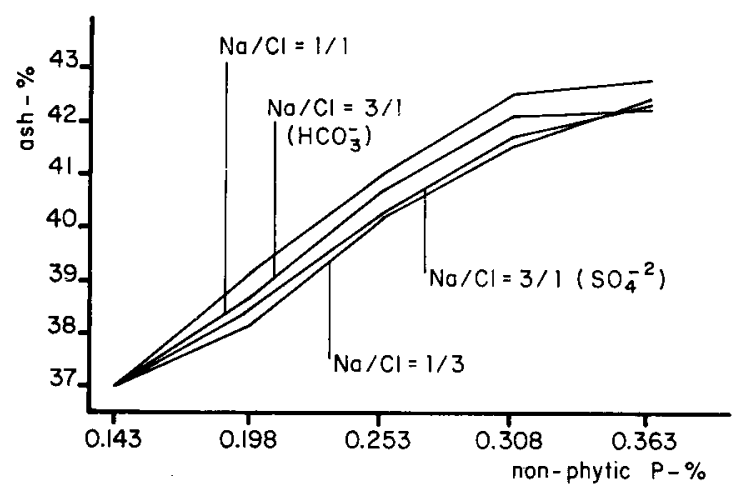

FIG. 6. - The eflect of non-phytic P p. Ioo and $\mathrm{Na}:$ Cl-ratio, combined with different anions on tibia ash-percentage (2nd experiment).

Effet de la teneur en $P$ non-phytique et du rapport de $\mathrm{Na}: \mathrm{Cl}$, associé de différents anions sur le pourcentage des cendres du tibia (2 épreuve).

availability in this mixed phosphate is comparable, but not much higher, than that from the best commercial sources of mono-and di-calcium phosphate. This is in agreement with the conclusion, which can be drawn from a comparison of the results of Brune and Günther (I96I), StAPPERs, BorgGreve and GrimberGEN (I974) and of the biological efficiency level of I2I, found for this Ca-Mg-Naphosphate (Rosin, I972).

The utilization of phosphorus not only depends on the absorption level in the intestinal lumen, but also on the reabsorption level of the renal tubuli. The reabsorption is considerably influenced by the P-level of the blood plasma (physiological saturation) and by the acid-base balance of the plasma (Na: Cl-ratio). The Na: C1-ratio can only have an effect upon the acid-base balance, if the anion is metabolizable $\left(\mathrm{HCO}_{3}^{-} / \mathrm{SO}_{4}^{-2}\right)$. The $\mathrm{SO}_{4}^{-2}$-ion may be considered to be partially metabolizable, if it can be used to meet the sulphate requirement of the chick. In the case of a diminishing $\mathrm{Na}$ : Cl-ratio, not only $\mathrm{NH}_{3}$ but also $\mathrm{HPO}_{4}^{-2}$ is being excreted to neutralize the urine (MONCIN, I968). This results in a decline of the utilization of dietary phosphorus, so that it takes longer to achieve physiological saturation. Figure 6 illustrates this thesis. Table 6 shows that an increase of the Na: Cl-ratio from I: I to 3: I with the metabolizable $\mathrm{HCO}_{3}^{-}$ion, increases the R.B.V., of DCP $\neq \mathrm{A}$ by $3 \mathrm{p}$. Ioo on the basis of the 4 tibia parameters. On the contrary, a narrower $\mathrm{Na}$ : Cl-ratio of $\mathrm{I}: 3$, reduces the utilization of phosphorus derived from DCP $\neq$ A by $\mathrm{I} 5$ p. Ioo, from Io3 to 88 . An increase of the Na: 
C1-ratio to 3: I with the $\mathrm{SO}_{4}^{-2}$-ion results also in a markedly lower utilization of the phosphorus (- I 5 p. IOo), which may point to the fact that the $\mathrm{SO}_{4}^{-2}$ is not metabolized, because of an excess of dietary $S$ under the given experimental conditions. The observations concerning the negative influence of acidosis on P-utilization and on the biological availability of $\mathrm{P}$ in DCP are in agreement with experimental results from BARZEL (I969) and NEWELL and BEAUCHENE (I975) with rats and from JAMBOR and PROCHAZKA (I977) with pigs. They observed that these acidstressed animals showed significant increases in urinary total phosphorus andcalcium excretions. SAUVEUR et al. (I977) have also shown that metabolic acidosis inhibits the renal conversion of $25-(\mathrm{OH})$-vit. D into $\mathrm{I}, 25-(\mathrm{OH})_{2}$ vit. D by about $40 \mathrm{p}$. IOO in rachitic chicks. The metabolically active $1,25-(\mathrm{OH})_{2}$-vit. D not only stimulates the renal P-reabsorption, but also the P-transport through the intestinal cell walls (WALLING, I 977). Consequently, this physiological condition due to an excess of anions, leads to a lower $\mathrm{P}-(\mathrm{Ca}-)$ retention.

Accepté pour publication en juillet I980.

\section{Acknowledgement}

The authors wish to make acknowledgement to Ir. R. MOERMAN of the Bureau for Biometric analysis of the Centre for Agriculture Research for his cooperation in the statistic evaluation of the experimental results, and to. L. VERMEULEN, E. VERHOEYEN and H. REYNTENS for their precious technical assistance during this investigation.

\section{Résumé}

\section{Valeur biologique relative des sources alimentaires de phosphore pour les poulets de chair}

Les valeurs biologiques relatives (R.B.V.) des sources suivantes de phosphore ont été déterminées : deux phosphates monocalciques (MCP), deux phosphates bicalciques hydratés (DCP). deux phosphates bicalciques anhydres (An DCP), deux phosphates défluorés (DFP), un phosphate de Ca-Mg-Na (CMP), un phosphate-mono-sodique (MSP), un phosphate-bi-sodique (DSP) (phosphate de référence), une farine d'os et de viande et un phosphate de Ca-Al-Fe (CAP). Deux épreuves ont été faites : un rapport croissant de $\mathrm{Ca}: \mathrm{P}$ ( ${ }^{\mathrm{re}}$ épreuve) et une teneur constante de $\mathrm{Ca}\left(2^{\mathrm{e}}\right.$ épreuve). L'effet du rapport $\mathrm{Na}$ : $\mathrm{Cl}$ était également considéré. Seuls les paramètres du tibia (résistance de l'os à la fracture, teneur en cendres, pourcentage de cendres et teneur en P) ont été impliqués dans le calcul des R.B.V.

Les poulets de chair ont été logés dans des batteries et dans des conditions pratiques normales (eau déionisée). Les rations, déficientes en $\mathrm{P}$, ont également été distribuées aux groupes expérimentaux uniformes, pendant une période d'anabolisme intense des minéraux (7-20 jours).

Les résultats des deux épreuves sont très analogues ( $1-8 \mathrm{p}$. Ioo). Les moyennes de R.B.V. des deux épreuves sont, en comparaison avec le DSP (= Ioo) : MCP $\neq \mathrm{A}=98, \mathrm{MCP} \not 1 \mathrm{~B}=93$, $\mathrm{DCP} \neq \mathrm{A}=\mathrm{I}$ оI, $\mathrm{DCP} \neq \mathrm{B}=92$, An $\mathrm{DCP} \neq \mathrm{A}=86$, An $\mathrm{DCP} \neq 86, \mathrm{DFP} \neq \mathrm{A}=96, \mathrm{DFP}$ $\not \mathrm{B}=95, \mathrm{CMP}=102, \mathrm{MSP}=96, \mathrm{MBM}=90$ et $\mathrm{CAP}=15 \mathrm{p}$. I oo. Des différences nettes de solubilité dans le citrate d'ammonium à 2 p. I oo ne correspondent pas à des différences analogues de R.B.V. L'utilisation (rétention) du $\mathrm{P}$ était très nettement favorisée par un rapport élevé de $\mathrm{Na}$ : $\mathrm{Cl}$, associé à un anion métabolisable. 


\section{References}

ammerman C. B., Douglas C. R., Davis G. K., Harms R. H., ig6r. Compatison of phosphorus availability assay techniques for chicks. Poult. Sci., 40:548-553.

ANDERson R., CREug E., Burroughs W., I966. A laboratory technique for measuring availability of feed supplements fed to ruminants (to be published).

Baruah J. N., Davies R. E., REID B. L., Couch J. R., i96o. Utilization of phosphorus from defluorinated and colloïdal phosphorus by chicks and laying hens. Poult. Sci., 39 : 843-849.

BARZEL, U. S., I 969 . The effect of excessive acid feeding on bone. Calci. Tissue. Res., 4, 94-I 00.

BRUNE H., GUNTHER K., I96r. Biometrie voti mineralstoffkomplexwirkungen und Vitamin D. 6. Mitteilung. Z. Tierphysiol. Tierernährg. Futtermittelk., 16, : 97-1 I8.

Damron B. L., Harms R. H., 1970. A comparison of phosphorus assay techniques with chicks. 7. Comparison of the relative performance of eight phosphate sources. Poult. Sci., 49 : I541I 545 .

Day E. J., Mc Naughton J., Dilworth B. C., I973. Chemical versus chick bioassay for phosphorus availability of feed grade sources. Poult. Sci, 52, 393-395.

Dilworth B. C., DAX F. J., I964. Phosphorus availability studies with feed grade phosphates. Poult. Sci, 40:1443.

Fritz J. G., Roberts T., Boenne J. W., Hove, E. L., 1969. Factors affecting the chicks requirement of phosphorus. Poult. Sci., $48: 307-320$.

Gillis M. B., Norris L. C., HeUser G. F., 1948. The utilization by the chick of phosphorus from different sources. Poult. Sci., $48: 307-320$.

Gil,is M. B., EDwards H. M. Jr., Young R. J., 1962. Studies on the availability of calcium orthophosphates to chickens and turkeys. $J$. Nutr., $78:$ I 55-I6I.

Gueguen L., I965. Contribution à l'étude de l'absorption intestinale et du mode d'excrétion du phosphore chez les animaux. Mededelingen van de landbouwhogeschool en de opzoekingsstations van de Staat te Gent., 30, 687-697.

GUEGUEN L., I970. Les critères de qualité nutritionnelle des compléments minéraux en alimentation animale. Bull. Soc. Scient. Hyg. Aliment., 58, I I5-I 29.

GüNThER K., I966 a. Uber die Wirkungsweise der D — Vitamine und ihre Bedeutung für die Tierernährung.

I. Mitteilung. Z. Tierphysiol. Tievernährg. Futtermittelk., 21:361-383.

GÜNTHER K., I966 $b$. Uber die Wirkungsweise der D - Vitamine und ihre Bedeutung für die Tierernährung.

2. Mitteilung. Z. Tierphysiol. Tierernährg. Futtermittelk., $22: 8-25$.

GÜNTHER K., TEKIN C., I968. Undersuchurgen über die Skelettentwikung und Ossifikation beim Küken.

3. Mitteilung : Die Ossifikation des Gesamtskelettes und der einzelnen Skeletteile bis zum 28. Lebenstag in Abhängigkeit von der Ca-P-verzorgung unter dem Einfluss von Vitamin D.

Z. Tierphysiol. Tierernährg. Futtermittelk., $24: 10-27$.

HuRwirz S., I964. Estimation of net phosphorus utilization by the slope-method. $J$. Nutv., 84: $: 83-92$.

Hurwitz S., COHEN I., BAR A., BORNSTEIN S., I973. Sodium and chloride requirements of the chick : Relationship to acid-base balance. Poult. Sci., $52: 903$.

JAMBOR V., Prochazka Z., I977. Einfluss einer unterschiedlichen Anionen- und Kationenkonzentration in der Diät auf die Ausnutzung von Kalzium und Phosphor bei Schweinen. Arch. Tievernähr., $27: 7$ or-7og.

Mc, Gifrivray r 978 . Biological availability of phosphorus sources. First Annual International Minerals Conference (St. Petersbrug Beach-Florida) : 73-86.

MoNGin P., I968. Role of acid-base balance in the physiology of the egg shell formation. World's P.S. Journal, 24 : 200-23o.

NELSON T. S., 1967. The utilization of phytate phosphorus by poultry. A review. Poult. Sci., $46: 862-87 \mathrm{I}$.

NELson T. S., PEELER H. T., I96r. The availability of phosphorus from single and combined phosphates to chicks. Poult. Sci., $40:$ I 32 I-I 328.

NELSON T. S., WALKER A. C., I964. The biological evaluation of phosphorus compounds. A summary. Poult. Sci., 43 : 94-98. 
Nelson T. S., MiLEs R. D., I972. Effect of calcium and phosphorus on energy utilization by chicks. Poult. Sci., 51, I 526-1540.

NEISON T. S., MILES R. D., I973. Effect of chemical and physical properties of phosphates on enlergy utilization by chicks. Poult. Sci, $52: 481-485$.

Newell G. K., Beauchene R. E., 1975. Effects of dietary calcium level, acid stress and age on renal, serum and bone responses of rats. $J$. Nutr., 105: 1039-I047.

Pensack J. M., 1974. Biological availability of commercial feed phosphates. Poult. Sci., 53 : I 43-I 48 .

Pensack J. M., Stokstadt E. L. R., i96r. Studies on the biological availability of inorganic phosphates for chicks. Poult. Sci., 40 : I 443.

RosiN G., I972. Hostaphos - ein Beitrag zur neuzeitlichen Mineralstoffversorgung heutiger Hochleistungstiere. Kraftfutter, $55: \mathrm{I}-3$.

Sauveur B., Garabedian M., Feliot C., Mongin P., Balsan S., 1977. The effect of induced metabolic acidosis on vitamin $\mathrm{D}_{3}$ metabolism in rachitic chicks. Calcif. Tiss. Res., 22 : I 2 I-I 24.

Sitappers H. P., Borggreve G. J., Grimbergen A. H. M., 1974. Fosforbronnen en fosforgehalten in slachtkuikenvoeders. Jaarverslag "De Schothorst ", I973-I974: I58-I63.

Sulitvan T. W., r966. A triple response method for determining biological value of phosphorus sources with young turkeys. Poult. Sci., 45: I $236-1245$.

Waldroup P. W., Ammerman C. B., Harms R. H., 1965. A comparison of phosphorus assay techniques with chicks. Poult. Sci., 44 : 1 $086-1089$.

WALLING M. N., I977. Intestinal inorganic phosphate transport. In Advances in experimental medicine and biology S. G. MAsSRy, E. RiTz, A. RAPADo, vol. I03. Homeostasis of phosphate and other minerals, I3I-I48. Plenum Press, London.

Watkins I. E., Mircheis H. H., I936. The phosphorus requirement of growirig chickens, with a demonstration of the value of controlled experimental feeding. Poult. Sci., 15: 32-4I.

YoshmA M., Hoshir H., 1977. Improvement of biological assay to determine available phosphorus with growing chicks. Jap. Poult. Sci., 14: 33-42.

Yoshida M., Ishikawa M., Nakajima H., Hotra S., I979. Solubility of phosphorus in citric acid solution as an index of biological availability. Jap. Poult. Sci., 16 : 290-292. 